\title{
The American Past in the Age of Fracture: episodes from the History Wars in the United States during the 1990s
}

\author{
Arthur Lima de Avila[1]
}

\begin{abstract}
In the 1990s, the United States faced several history wars about the meaning of the national past for that present. Among these, we can highlight the controversy over National History Standards, which sought to minimally incorporate certain multicultural perspectives for the teaching of history in the country, and the Crossroads exhibition, imagined as a critical reflection about the end of World War II and the use of atombombs against Japan. These disputes, the article argues, can be understood in the broader context of the culture wars that raged in the period as well as the return to the past driven by the gradual erosion of futuristic projects during those years. Finally, we briefly discuss the impact of the history wars in the American disciplined historiography.
\end{abstract}

Keywords: history wars; National History Standards; Crossroads.

O passado norte-americano na Era da Fratura: episódios das guerras de história nos Estados Unidos da década de 1990

\section{Resumo}

Na década de 1990, os Estados Unidos enfrentaram diversas guerras de história sobre o significado do passado nacional para aquele presente. Dentre elas, podem-se destacar as controvérsias sobre os National History Standards, que buscavam incorporar minimamente certas perspectivas multiculturais ao ensino da história no país, e sobre a exposição Crossroads, imaginada como uma reflexão crítica sobre o fim da Segunda Guerra Mundial e o uso das bombas atômicas contra o Japão. Essas contendas, argumenta o artigo, podem ser entendidas a partir do contexto mais amplo tanto das culture wars que grassavam no período quanto de um retorno ao passado impelido pela gradual erosão de projetos futuristas ao longo daqueles anos. Finalmente, discute-se brevemente o impacto dessas guerras de história na historiografia disciplinada estadunidense.

Palavras-chave: guerras de história; National History Standards; Crossroads.

\section{Le Passé Américain à l'Ére de Fracture: épisodes de de guerres d'historire aux États-Unis des années 1990}

\section{Résumé}

Dans les années 1990, les Etats-Unis face à plusieurs guerres d'histoire sur le sens du passé national pour ce présent. Parmi eux, nous pouvons souligner la controverse sur les National History Standards, qui a cherché à incorporer au minimum certaines perspectives multiculturelles pour l'enseignement de l'histoire dans le pays, et l'exposition Crossroads, imaginée comme une réflexion critique sur la fin de la Seconde Guerre Mondiale et l'utilisation des bombes atomiques contre le Japon. Ces différences, l'article soutient, peuvent être comprises dans le contexte plus large de la guerre des cultures qui ont fait rage dans la période, ainsi que le retour vers le passé entraîné par l'érosion progressive des projets futuristes au cours de ces années. Enfin, nous discutons brèvement l'impact des guerres d'histoire dans l'historiographie disciplinée américaine.

Mots-clés: guerres d'historie; National History Standards; Crossroads.

\section{El Pasado Americano en la Era de la Fractura: episodios de las guerras de historia en los Estados Unidos de la década de 1990}

\section{Resumen}

En la década de 1990, los Estados Unidos se enfrentó a varias guerras de historia sobre el significado del pasado nacional para aquel presente. Entre ellas, podemos destacar la controversia sobre los National History Standards, que pretendía incorporar mínimamente ciertas perspectivas multiculturales a la enseñanza de historia en el país, y la exposición Crossroads, imaginada como una reflexión crítica sobre el final de la Segunda Guerra Mundial y el uso de las bombas atómicas contra Japón. Estas disputas, argumenta el artículo, se pueden entender en el contexto más amplio tanto de las guerras culturales que se desencadenaran en el período cuanto de un retorno al pasado impulsado por la erosión gradual de proyectos futuristas largo de esos años. Finalmente, se discute brevemente el impacto de las guerras de historia en la historiografía disciplinada americana.

Palabras-clave: guerras de historia; National History Standards; Crossroads. 
That's one of the central problems of history, isn't it, sir? [...] the fact that we need to know the history of the historian in order to understand the version that's being put in front of us.

(Barnes, 2012, p. 13)

\section{Introduction}

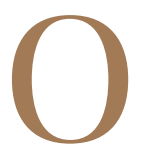

ne of the principal characteristics of Western societies in our time is a certain fixation with the past, symbolized, amongst other things, by its mercantilization, with its remains almost obsessively being made into heritage, various 'retro' fashions, and the chique nostalgia of some (De Groot, 2009; Hartog, 2014). Sign of an exacerbated presentism, which transforms the time before now into a type of 'slave' of its own necessities, or the symptom of the global collapse of futuristic and/or utopians projects, the fact is that, to cite Geoff Eley (2011, p. 557), contemporary sensitivity invites us to take a position in relation to various types of past, each more evanescent than the other. In this scenario, we are constantly questioning what we were, what we are, or - at least - what we could have been (Eley, 2011, p. 558).

Perhaps as a consequence of this, the last three decades have witnessed the explosion of various history wars ${ }^{2}$ in several countries, such as Germany, Australia, South Africa, ${ }^{3}$ and, the case which most interests me, the United States, when in the 1990s there was the famous "fight for the soul of America," to use Andrew Hartman's (2015) excellent metaphor. From the use of the atombomb to the conquest of the West, nothing was untouched by the conflicts of those years; more than simple historiographic disputes about empirical, factual, or epistemological questions, the history wars involved wide-ranging sectors of society, had great public repercussion, and raised divergences, especially political, between the professional/academic representations of the past and those of other social actors. Not infrequently, the profession saw itself confronted by critics which challenged its authority to speak about and for the past and questioned its legitimacy as the 'sole guardian' of the national past. Perhaps shocked, US historians discovered that not only could their interpretations be very unpopular among their contemporaries, they could be openly rejected by them.

This article aims to minimally contribute to the theoretical and historiographical debate about US history wars based on the study of some of its broadest cultural roots and its effects on the discipline of history. It is thus divided into three parts, in addition to this brief Introduction. In the first part, I look

\footnotetext{
2 The expression history wars seems to be derived from culture wars, a more wide-ranging US political phenomena in the 1990s, principally, in relation to the struggle to define America, to use James Hunter's (1992) classical formula. As far as I know, its first well known use is in the title of the seminal work organized by Edward Linenthal and Tom Engelhardt (1996) about the 'battles of the US past' in that decade. The term ended up being imported by Stuart MacIntyre and Anna Clark (2003) to refer to the public confrontations about the Australian past in the 1990s, and since then has been applied to conflicts about the past in various other societies.

${ }^{3}$ For the Australian and South African history wars see, respectively Maclntyre and Clark (2003) and Rufer (2010). For the German Historikerstreit, see Baldwin (1990).
} 
at possible origins of the history wars both in the disassociation between the discipline of history and the idea of a nation and in the regime of historicity which appears to order our current relationship with time. Following this, I discuss two public disputes about the national past in the United States in the 1990, during the so-called 'Age of Fracture' (Rodgers, 2011):" the controversies about the National History Standards (NHS) and the script of the Crossroads exhibition, prepared by the curators of the US National Air and Space Museum (NASM). Finally, in the epilogue, I point to some of the effects of the battles of these local history wars on the discipline of history in the US.

\section{Et pluribus, unum? The fracturing of national history in the United States}

In the United States, the 1990s were hard years for the profession, but not necessarily for the past itself. As presented by Michael Kammen (1997, pp. 200-201) in his classic analysis, the history boom of those years transformed 'memory' and 'history' into 'panaceas' for an epoch in which the nation seemed to suffer from tremendous anxiety. In a context of intense 'cultural wars' and even an apparent desegregation of the idea of the 'United States,' the past became one of the most important ideological battlefields in the culture wars (Hartman, 2015, pp. 253-284).

But what seems to have impelled this, often dramatic, American, return to the past? The response seems to be linked to two fundamental questions: in first place the slow separation between 'historiography as a discipline' and the idea of the nation that occurred during the second half of the twentieth century and consolidated, as it were, in the last three decades of that century; in second place, to the broader unraveling of 'historical meaning' verified at the same period, based on Chris Lorenz (2014, pp. 43-62) calls the 'blurring' of the temporal lines of the past, present, and future, as a consequence of the (re)emergence of demands previously thought of as surpassed.

Historiography as a discipline emerged with the principal, but not unique, function of conferring legitimate, and allegedly scientific, genealogies to the nations in formation and consolidation during the nineteenth century. Anchored on an ever more extensive network of places of production, historians became the "guardians of the national past," in the metaphor of Gerald Nash (1993, p. 273), asserting the 'historicity' and the 'naturalness' of nations. History was thereby transformed in the process of their origin and development, or their failure and disintegration, with the nations now imagined as being both the principal characters of historiographic texts and the privileged loci for carrying

\footnotetext{
${ }^{4}$ According to Rodgers (2011, pp. 8-9), the 'Age of Fracture,' which began during the turbulent years of the 1960 s and 1970s, had the principal characteristic of the fragmentation of words and ideas in common about what being 'American' meant and means and what historically constituted this being. According to him, "strong metaphors of society were supplanted by weak metaphors. Imagined collectivities diminished; notions of structure and power were thinned out. [...] the last quarter century was a period of desegregation, a great era of fracture" (Rodgers, 2011, p. 3).
} 
out the actual historic transformation (Lorenz, 2010, pp. 75-80). As a consequence, it was attempted to prevent rival narratives to this teleology from emerging, or at least obtaining the same public legitimacy of those produced by the discipline. Thought of as a type of 'biography of the nation,' historiography supplied the foundations of the imaginary unification and the creation of 'citizens' whose loyalties, especially in countries with a large immigrant population, or with important ethnic minorities, had to be guaranteed (Lorenz, 2010; Berger, 2007, pp. 30-62).

In the United States, this 'biography of the nation,' or what Nathan Huggins (1991, pp. 25-48) called "American metahistory," has acquired various contours since the end of the nineteenth century, but in general terms maintained as some of its main pillars an optimistic vision of the national past, a belief in the continuous progress of America, and the defense of its exceptional nature compared with other countries around the globe. From the Turnerian defenders of the frontier thesis to the consensualists from the 1950s, passing through the Dunning School, in US historiography there prevailed an at times implicit commitment to the legitimation of what the United States were and should be, without any great space for the critiques of the dominant order. ${ }^{5}$ In this way, as made clear by Novick (1988, pp. 47-85) and Thomas Bender (2011, pp. 369$389)$, to a large extent this involved the silencing or erasing of various characters and processes from US history and the shaping of narratives which, even when they were not openly nationalist, racist, and sexist, gave an ideological seal of approval to various forms of discrimination and exclusion.

Nevertheless, from the 1950s and 1960s onwards, the marriage between historians and the nation, which in fact had never been very tranquil, began to collapse, principally because of the criticisms of the New Left and the New Social History which correctly identified the role of historiography as being the guarantor of the status quo. Although, the emergence of new historical objects and characters due to the inspiration of New Social History, did not annul the final possibility of its integration in national history, at the very least this became very problematic (Novick, 1988, pp. 469-523). How could one, for example, represent the past of the Afro-Americans and Amerindians of the United States, without mentioning their brutal and violent exclusion from the American 'imagined community' for centuries? How could the experiences of various immigrants be narrated without necessarily assuming a rapid and efficient process

\footnotetext{
${ }^{5}$ The frontier thesis inspired by the ideas of Frederick Jackson Turner postulated that the expansion of the Western frontiers of the United States was fundamental for the emergence of a truly American democracy, since it served to 'Americanize' the immigrants and to incorporate millions of hectares of free land into the nation. While the 'consensualists' stated that there was a 'historic consensus' about determined values and ideas in the United States, such as economic freedom, political democracy, and Judeo-Christian morality; this consensus, according to them, had prevented the country from facing conflicts similar to the wars and revolutions of the Old World. Finally, the 'Dunning School' argued about the supposed 'civilizing' role of slavery on American soil, minimizing its violence and defending the legitimacy of white supremacy as an instrument of control of Afro-American populations. All these interpretations, even if heterogeneous and continually contested by a series of historians, present a progressive and optimistic vision of the country's past. For an introduction to all of them, see the already cited work by Peter Novick (1988) and the classic work by lan Tyrrell (1986).
} 
of assimilation? How to speak of American capitalism without mentioning its enormous human and environmental costs? Or, to raise the question of space, how to write the history of various national frontiers, fluid spaces of integration and separation, and their creation, based on a strictly national logic?

A second process, internal to the discipline, also contributed to the gradual split between history and nation: the process of super-specialization, or, to use the expression of Ian Tyrrell (2005, pp. 25-40), the 'feudalization' of historiography as a discipline in a series of fields and subfields which did not necessarily conversed between themselves or did not even have national history as their general horizon. The time arrived when, in the excellent biblical metaphor used by Novick (1988, p. 573), no king seemed to reign in Israel.

\section{In the United States, the 1990s were hard years for the [historical] profession, but not necessarily for the past itself.}

In addition to the apparently interminable jeremiads about the 'crisis of history' the theoretical developments of this 'fragmentation' of historiography are well known: the new social history was itself the target of harsh and due criticism from cultural history and, in an even more radical manner, for its later 'linguistic turn. ${ }^{6}$ In a few decades the old certainties about the 'objectivity' and 'impartiality' of history were submitted to systematic scrutiny which, for its own good, made the discipline meditate on its broadest epistemological pillars. While, evidentially, this criticism had (or should have had ...) a liberating effect on the most conservative of the Humanities, one of its collateral effects was the undermining of that practical pillar which had legitimated it for more than a century: the nation's sustenance (White, 2012, p. 128). It is no surprise that the history wars ended up confronting historians who assumed an assumedly critical posture in relation to the 'biography of the nation' and an audience which, despite the changes in academic historiography, continued imagining history in these exact terms, as Antonis Liakos (2008-2009, pp. 57-58) put it: "the national public spheres are still dominated by national history. As a consequence, attempts to dissociate history from the nation often result in history wars."

To a certain extent, the emergence of these new historiographical demands was linked to the recognition of the existence of 'historical wounds,' in the meaning used by Dipesh Chakrabarty (2007, p. 77-87), which had been constituents of the American nation itself. As William Faulkner said, for some the past not only was not dead, but it was not even past. For the United States to be

${ }^{6}$ In relation to the impact of these turns on US historiography, see the recent dossier in the American Historical Review (2012) 
able to take into account the injustices of its present, it was necessary to confront what Patricia Limerick (2001, pp. 33-73) called the 'haunted America,' in other words, the ways the diverse legacies from the past, even if constantly denied and/or minimized, continued subsisting and frightening the present. To the extent that the present refuses to elaborate this violence or minimally recognize it, under the guise of different types of negationisms or amnesias, the more this 'hot' past, in Lorenz's (2014) understanding, returns to haunt the living - and in part it seems that this was one of the roots of the US history wars.

As will be seen, the minimal incorporation of multicultural histories, for example in the curricula of local schools, as well as the ethical consideration of the use of the bombs against Japan, seems to obey this logic, to the extent that they sought to illuminate certain aspects of the past not easily incorporated in that progressive and optimistic meta-history described above. In other words, it was as if the elements repressed or denied by this narrative suddenly returned to the surface of American society with the clear purpose of demanding their public working-through. Otherwise, how can the virulence of conservative responses to these demands be understood?

On the other hand, the disjunction between a historical discipline increasingly less and less interested in being the 'guardian of the nation' and the demand of substantial parts of the audience that it be so, appears to have generated a type of nostalgia for a supposedly 'less complicated' history, to use the expression of an American commentator (Hartman, 2015, p. 272), i.e., one centered on the principal men and national events and with the function of stimulating a sense of patriotism among its citizens. For these critics, the 'new history,' pejoratively called 'revisionist,' with its cacophony of characters, themes, and objects which were until then (relative) outsiders in the public sphere, signified the de-structuring of a way of understanding history which resulted in a desire for a stable and static past without conflicts:

As the very language for society threatened to break into fragments, the past became a sphere onto which desires for community and cohesion could be projected. [...] A sense of living within fragmenting and accelerating time made history a point of acute importance. (Rodgers, 2011, p. 221)

In the last instance, the 'Age of Fracture,' appears to be related to the exhausting of large collective projects and the unavailability of the national language typical of late capitalism and its cultural logic, as presented by Fredric Jameson (1984, p. 65). The melancholy for the 'loss' of a determined history, which could serve as the fundamental nexus for determined identities, appeared to generate a nostalgia for a time in which the 'true history' was spread through the four corners of the country without being threatened by 'politically correct' or 'anti-American' impostures. Therefore, if the present was the source and stage of uncertainties and virulent confrontations, the past was seen as a type of gold age, the good old days when men were men, civilization prospered and the moral values of the West were defended and respected. 


\section{Museums and curriculums: how many battles make a history war?}

This broader context helps understand American history wars in the 1990s and especially their public virulence. Of the various history wars fought during that period, the two best known were those related to the National History Standards and the Crossroads exhibition about the end of the Second World War and the use of the atom bombs against Japan, in the National Air and Space Museum (NASM), both reaching their peaks between 1994 and 1995. In the two conflicts, which are often confused, historians found themselves confronted with a torrent of public criticism, especially political, of their representation of the US past, coming from different groups, moved by various interests.

In the first case, a group of professional historians, pedagogues, professors, and middle and high school teachers from all over the country prepared voluntary national curriculums for the teaching of history, with public funding from the National Endowment for the Humanities (NEH). ${ }^{7}$ The project began in 1992 and had the aim of incorporating some of the postulates of the new social history to the US classrooms, overcoming something which, in the vision of its idealizers, was a sterile history centered on the great names and deeds of the past and seen as excessively nationalist. What is of interest here is both pedagogical and political: in the first case, the aim of the directives was to go beyond that compendium of names, dates, and facts, which according to Gary Nash et al., (1997, p. 25) and Linda Symcox (2002, pp. 25-28), still composed the core of the teaching of history in the schools of the country and, thus, to make the relations of students with the past more complex.

Although the work of preparing these documents had not been without conflict, the controversy about them was made manifest after the publication of an editorial by Lynne Cheney, former president of the NEH and one of the inspirers of the project, in The Wall Street Journal, in October 1994. In this, the Republican lamented the 'kidnapping' of history of the country by 'politically correct' groups, condemned the absence of 'important figures,' such as George Washington, from the Standards and criticized the 'absence' of 'traditional history' from the document. However, beyond the more specific factual questions, the problem of the NHS was, according Cheney, its 'negative' vision of the US historical experience, which threatened to 'weaken' the patriotism of the youth of the country: "We are a better people than the National Standards indicate, and our children deserve to know" (Cheney, 1994, p. E2). It mattered little to Cheney the fact that the adoption of the NHS was voluntary; for her, the authors of the documents were trying to impose a perfidious 'official history' on the country.

A torrent of assaults immediately followed the editorial, with conservative journalists, broadcasters, and historian, as well as the general public, taking

${ }^{7}$ The NEH is a public agency aimed at developing and funding research and other activities in the humanities in the United States. During the 1980s and 1990s, the agency was continually attacked by republicans for its supposed politicization of the human sciences and for its alleged support for 'Anti-American' productions, as highlighted by Andrew Hartman (2015, pp. 217-218) in his history of the 'culture wars' of that period. 
sides against NHS. Shortly after the publication the article of Cheney, the histrionic broadcaster Rush Limbaugh (apud Hartman, 2015, p. 273), one of the principal propagators of the conflict, delivered his usual diatribes against the 'politically correct intellectuals of the country,' and, perhaps converted into a late Rankean caricature, stated that history was something very simple, in other words, 'merely happened and nothing else:'

\begin{abstract}
The problem you get into is when guys like this try to skew history by saying: 'well, let's interpret what happened because maybe we can't the truth in the facts, or at least we don't like the truth as it's presented. So let's change the interpretation a little bit so that will be the way we wished it were.' Well, that's not what history is. History is what happened and history ought to be nothing more than the quest to find out what happened." (Limbaugh apud Nash et al., 1997, p. 6)
\end{abstract}

Generally speaking, in the following months, a large part of the critics repeated the accusations of Cheney and Limbaugh: the curricular guides were 'excessively politically correct and multicultural,' too focused on the 'subaltern' (women, Afro-Americans, and indigenous peoples, for example), extremely critical of capitalism and, finally, 'anti-western,' since they supposedly rejected the 'European' inheritance of the country. Some conservative columnists and intellectuals, such as John Leo, John Patrick Diggins, and Walter McDougall, went further and accused 'politically correct historians' of having 'kidnapped' national history and transforming it into a litany of suffering which aimed at the 'Balkanization' of the United States' past, and consequently of attacking the very foundations of the American idea of et pluribus unum. The journalist John Leo summarized this point of view well when he declared: "if you see America as inherently oppressive, then the only possible history is that of the gradual growth of more and more rebellions against the dominant white elites" (Leo apud Nash et al., 1997, p. 192).

As can be inferred in this criticism, for some conservatives, the old history centered on great men from the past and on 'American values' was still the 'true' national narrative, notwithstanding any 'fashions' and appeals to what was considered as a history which only aimed to "increase the self-esteem of minorities" who, according to them, "had contributed little to Western civilization" (Hartman, 2015, pp. 253-284). Walter McDougall, professor of American History in the University of Pennsylvania, left it clear that, more than one or other factual question, the greatest problem of the Standards was precisely their political scope, especially in relation to the history of the nation and their connection with 'Western values.' In relation to this, McDougall (1995) was clear: any attempt to minimize the global positive impact of Western civilization was something to be condemned. 'The decency of the life of the next generation', according to him, depended on this.

Due to this position, McDougall (1995) harshly censured any attempt to make American history complex for the students of the country's middle and 
high schools; before learning about the greed and cynicism which were also part of the national past, he suggested that students should learn about the 'exceptional deeds' of American civilization and the 'numerous sacrifices' involved in its creation and preservation. The supposed attempt to 'raise the self-esteem' of ethnic minorities and subaltern groups was something praiseworthy, but it could not be at the cost of denying the centrality of 'freedom' and 'equality' for national history. According to McDougall (1995), in short, the struggle against the NHS was part of a great war for the preservation of the 'central' aspect of the history of the country at a moment which is was supposedly under heavy attack from the ranks of the 'politically correct.'

\section{If the present was the source and stage of uncertainties and virulent confrontations, the past was seen as a type of golden age, the good old days}

John Patrick Diggins, Professor of Intellectual History in the City University of New York (Cuny), repeated the admonitions of McDougall, adding to them a harsher critique of what he considered the most nefarious aspect of the New Social History, represented by its directives: its 'mystification' of the subaltern classes. According to Diggins (1997, p. 10), social history, as outlined in the NHS, did not teach American youths about the political liberties which sustained the country, to the extent that it neglected the actions of the great men who had struggled to guarantee them to all Americans. In the view of this professor, the idea that the history of the United States began with contact between Amerindians, Africans, and Europeans was a 'politically correct' fallacy. According to Diggins (1997, p. 9), history was thus divided between those who made it and those who endured it, with it being 'natural,' according to his own words, that people would identify with the former:

Once upon a time it was as natural to identify with those who made history and to neglect those who simply endured it as it was to identify with an athletic star to the neglect of the spectators, whose very attendance indicated that they, too, enjoyed the same visceral identification with the superior and the glorious.

The perspectives of these professors can be seen as conservative paradigmatic form of imagining the history of the United States in the molds of a national meta-history described in the first part of the article. In the interstices of their criticism of the NHS, there emerged the idea of the American past as being something to be celebrated and shared by the country's population, especially in relation to the Western heritage and its place in the international concerto of nations, as the corollary of the erasure, or, at least, the silencing, of 
any histories which could put this idea in question. Centered, as McDougall stated (1996) on another moment, in a series of 'dates, facts, and central characters' which exemplified the 'search for freedom and self-realization' as the principal motif of the national experience, the history imagined by the professors could not admit any melody dissonant to the central harmony under the risk of losing its meaning. The 'historic wounds' thereby remained without recognition, because they were unimportant for the 'central theme' of the history of the country.

McDougall and Diggins' voices, even if minoritarian among professional historians, seemed to echo the feeling of various other conservative commentators about the apparent need to preserve certain constancy for the past in the context of the cultural wars which followed the turbulent decades of the 1960s and 1970s, the defeat in Vietnam and the end of the Cold War. While the present was presented as a crisis, that is, as a locus of instability, division, and profound ideological conflicts, only a history which reaffirmed the continuity and stability of the nation could save it from what, in the eyes of conservatives, was the almost irreversible decline of its soul:

\begin{abstract}
The goal of history was to inculcate a love of country, plain and simple. Such an objective became more paramount than ever with the loss of national purpose that accompanied the end of the Cold War - and more poignantly, the crisis of national identity that ensued alongside the decline of American power made manifest in the jungles in Vietnam. (Hartman, 2015, p. 276)
\end{abstract}

After months of controversies, echoed in newspapers, the radio, and the television, and with the organizers of the NHS being submitted to increasingly histrionic attacks, the peak of the conflict was the victory of a senate resolution rejecting the guides, even with only a symbolic value, by 99 to 1 , voted on in January 1995. According to the senators, US taxpayer money could only fund projects which, in their words, had "decent respect for the contributions of Western civilization to the world, the history of the United States, and the increase of prosperity and freedom around the world" (141 Cong. Rec. S1282 - Senate Resolution 66, 1995). Justifiably, the voices of respected intellectuals, such as Eric Foner and Joyce Appleby, were raised against this this attempt by the legislators to create a mockery of official history for the country. Important newspapers, such as the New York Times, also denounced the authoritarianism implicit in the motion (Nash et al., 1997, p. 236). Although echoed publically, their denunciations had little practical effect. The first version of the NHS was doomed. With the message having been given by the politicians and incapable of opposing the senate resolution, there was no other solution for the organizers other than to amend the directives, with the publication of its final version a year later. Some more exalted conservatives continued to attack the document, but its final format, supposedly 'more patriotic' than the first, pleased the majority of the critics and was thereby finally released for the schools (Symcox, 2002, pp. 147-149). 
The Enola Gay Controversy was as noisy as that of the NHS. Since the 1980s, there had existed an important lobby of politicians, the military, and the Air Force for the restoration of the Enola Gay airplane, until then abandoned in a warehouse in Maryland. At the beginning of the 1990s, however, the NASM obtained sufficient funds to start the restoration of the aircraft which had dropped the atom bomb on Hiroshima. The goal was the use the airplane in an exhibition about the fiftieth anniversary of the end of the Second World War and to remember its role in the ending of hostilities between the United States and the Japanese Empire.

\section{For some conservatives, the old history centered on the great men of the past and on American' values was still the 'true' national narrative, notwithstanding any 'fashions.'}

Prepared by Martin Harwit, director of NASM, and by his curators, some of whom were professional historians, Crossroads sought to contextualize the use of atombombs in Japan, the intention of the US government in ordering the destruction of Hiroshima and Nagasaki and its legacy for modernity. In other words, the organizers of the exhibition sought to open a space for critical reflection about the bombs and the 'AtomEra' based on the exhibition of a series of artifacts, ranging from clothes and materials rescued from the ruins of the Japanese cities to letters sent to the front by US soldiers, culminating with the exhibition of a restored and imposing Enola Gay (Linenthal, 1996, pp. 28-32). The preparation of this first script was not without discordances, as Harwit (1996) himself stated in his report on the episode, but they assumed a gigantic proportion with its leak to the media in 1994.

Opposed to the positions of the organizers, the veterans who advised them delivered the script to the press. A devastating critic published in the Air Force Magazine, journal of the powerful Air Force Association, attracted the anger of politicians and former military concerned with the excessive 'relativism' of the planned exhibition. In the following months, the document would be the target of a series of attacks against what its opponents imagined was an 'excessive concern' with the 'Japanese side' of the war, the 'absence' of an 'effective contextualization' of the decision to use the atombombs, the 'lack' of explanations about the 'brutal behavior' of the Japanese in the Pacific, and finally the supposed antipathy of the organizers for the US soldiers and their sacrifice for their country. The American Legion, the organization of the veterans of the US Armed Forces, considered the initial plans as nothing less than 'insulting' and 'offensive' to the memory of the soldiers who gave their lives for the United States (Dubin, 1999, pp. 162-163). John Correll (1994a), editor of AFM, 
stated that undoubtedly the use of the bomb against the 'Japanese enemy' was one of the most ethical and least ambiguous events of the twentieth century, due to the number of future lives it saved. By not treating this event with the 'due respect,' those who prepared the script proposed in the vision of Correll (1994b), a posture that was excessively 'revisionist' about the Second World War and its effects in the present.

One of the principal arguments of the critics of Crossroads was the supposed incapacity of contemporary historians to judge events in the War in the Pacific, principally because they had not been witnesses of or participants in it. One of the veterans, for example, stated that 'he did not understand' the reason for 'so much sympathy' for those who wanted to kill him, except due to a 'lack of knowledge of the 'real' history. In his perspective, the organizers of the exhibition had to stand alongside the Americans who suffered during the war, and not defend their tormentors (Dubin, 1999, p. 192-193). According to these critics, the 'real history' was simple and easy to access; if only Harwit and his companions would abandon the 'revisionist' posture which supposedly moved them and recognize the supposed 'intrinsic truth' of the former soldiers' testimonies (Newman, 2007, pp. 168-170).

The exhibition of photos of the dead and injured in the attack and artifacts collected on the ground zero of the explosions was the target of the special wrath of the veterans and their allies; according to them, these pieces were only in the script because of their 'emotional value,' and their exhibition supposedly contributed 'nothing to the 'proper' understanding of the War in the Pacific and the decision to drop the atom bombs on Japan. According to these critics, the bombing of Hiroshima and Nagasaki could not be understood without Japanese cruelty, exemplified in episodes such as the Rape of Nanking and the Bataan Death March, being taken into consideration. Similarly, some engaged in counterfactual speculations, even without any empirical proof, stating that the use of bombs had avoided an invasion of Japan which would have cost millions of lives - one commentator even raised the specter of the Holocaust by stating that 'six million souls', the supposed cost of an attack by land, had been saved by the bombing of the Japanese cities (Dubin, 1999, p. 214).

The commander of Enola Gay, Paul Tibbets, called the script a "pile of junk," with other voices echoing similar arguments (Correll, 1994a). Even with the explanations of the organizers and support for the exhibition by certain sectors of the press, the military, veterans, journalists, and politicians pressured public opinion to such an extent that, as in the NHS episode, the controversy reached its peak in a senate resolution rejecting Crossroads in September 1994. During the session which voted on this motion, one of the Republican senators stated that the mission of the museum was to 'preserve the history' of the United States, not to 'rewrite it.' Another also accused the script of being a further attack of the 'radically politically correct' against 'real' national history:

Whereas, in memorializing the role of the United States in armed conflict, the National Air and Space Museum has an obligation 
under the Federal law to portray history in the proper context of the times: Now, therefore, be it Resolved, That it is the sense of the Senate that any exhibit displayed by the National Air and Space Museum with respect to the Enola Gay should reflect appropriate sensitivity toward the men and women who faithfully and selflessly served the United States during World War II and should avoid impugning the memory of those who gave their lives for freedom. (140 Cong. Rec. - Senate Resolution $257,1994)$.

With no way out and weakened by months of public conflicts, the board of NASM shut down its plans for Crossroads. Only the restored fuselage of Enola Gay and videos about its mission over the Pacific were exhibited in its place, as well as its later restoration. No mention was made of the wider consequences of the attack on Japan. The exhibition became a public success, attracting more than four million people during the three years it was open to the audience (Linenthal, 1996, pp. 45-58).

How then did professional historians react to these conflicts? In 1995, for example, the Journal of Social History, one of the most important periodicals of US professional historiography, published a dossier which sought to analyze and find solutions for the problems presented by the conflicts of the previous years. Focusing principally on the question of the NHS, the contributors asked themselves about the motive for what Peter Stearns $(1995$, p. 7$)$ called an "uncivil war" of conservatives against social history. Also echoed by Gary Nash (1995, pp. 39-49) and Roy Rosenzweig (1995, pp. 99-107) in their contributions, Stearns' (1995, pp. 10-12) principal argument was that the controversy about the Standards was especially the result of a clash between two very antagonistic visions of history: one was focused on the history of the masses, on the complexity of the past, including its obscure aspects, and the rejection of the 'history of great men;' the other, in turn, was the inverted spectrum of this: the search for stability and optimism in the past, the veneration of great figures, and the cult of a very antiquated nationalism. It was therefore no surprise that the historians did not manage to construct bridges between them and their critics: there was not a sufficient middle ground for this.

Gary Nash (1995, pp. 44-46), who, as the coordinator of the NHS, was at the eye of the storm, appears to have perceived the political scope of the narratives in play by stating that, even with a certain amount of exaggeration, that the principal threat of the new American social history to conservatives was its revelation that the US nation had never been as unified as the more extreme nationalists imagined. Much to the contrary, the history of the United States was, since the arrival of the first Europeans on the shores of Virginia, filled with various conflicts, tensions, and violence. In relation to this, Nash (1995, p. 45) stated that, understandably, any form of imposition of a single form of 'American culture' or vision of the country's past was 'anti-democratic' (Nash, 1995, p. 45). And, in his view, it was exactly this which the conservatives, shielded by senate resolutions had decided to do. 


\section{Epilogue}

These history wars seem to demonstrate precisely that disciplinary disassociation noted above between 'history' and 'nation' and its political and public results, especially because of the expectations of some important social sectors about what they imagined to be the major function of history. One the one hand, there were historians and other intellectuals interested in the problematization of the idea of nation and in the minimum recognition of certain 'historical wounds' inseparable from its formation and legitimation; on the other were those who, due to political calculation or real sincerity, believed that any emphasis on the obscure aspects of the country's different pasts would contribute to the weakening of national identities. Although empirical and factual arguments were used by both sides during the conflicts, its final scope, to cite the considerations of Liakos (2008-2009, pp. 73-74), were not necessarily cognitive, but political: it involved the use of the past to take into account anxieties and uncertainties of then and/or to support certain political projects.

\section{The controversy about the Standards especially were the result of a clash between two very antagonist versions of history}

For part of the audience, as perceptibly noted by Tom Engelhardt (1996, pp. 210-249), the new histories appeared to challenge the order and stability that they found in the past. Given a present which was thought of being ever more unstable and at certain moments almost incomprehensible, the nostalgia for histories about the golden age of 'victorious America' emerged as one of the central themes of criticisms of the NHS and Crossroads. To a certain extent, the conservatives and their sympathizers continued to sustain the centrality of the 'American historical metanarrative' for the national self-definition of the United States and denied legitimacy to any history would minimally question this meta-narrative. However, for this, it was necessary to maintain a sanitized posture about the US past, one in which the 'historical wounds' of the nation did not threaten its present and past and in which what we can call the pain of history was absent.

Could this, for example, not have been the motive for the unmeasured reaction to the incorporation of subaltern voices and criticisms to the teaching of national history, considered not so much as 'false histories,' but as 'dangerous' histories? Was this not one of the reasons for the attacks on Crossroads and its creators? Was this not the cause of the conservative fear that the nation was under a 'politically correct' attack? Was this not the root of their fears in relation to the 'fragmentation' stimulated by histories with which they could not agree with politically? 
On the other hand, and this is quite important for current professional historians, these history wars demonstrate, at least in an initial view, the difficulty, in not the incapacity of the discipline from understanding or finding a new public function after its (acrimonious?) divorce from the nation. The US controversies are a good example of this, to the extent that in both the conflict about the NHS and the Enola Gay controversy, the profession suffered important defeats. It is evident that part of this occurred for obvious reasons: the absence of the resort to the symbolic strength of votes in Congress or to the pure and simple blackmailing, both used with sui generis ability by professional politicians. Nevertheless, the perceptible frailty of the position of historians is symptomatic of the tense and contradictory modes through which disciplinary legitimacy seems to be thought of by part of this public (Nash et al., 1997, pp. 218-221). For it, historiography, when it is not in its traditional function of being supportive of the nation, did not seem to have any more authority to deal with the past than other modes and/or institutions which equally vied for acceptance and the ultimate word, so to speak, about what the past should mean.

The reaction of the American historians is paradigmatic of this moment, as demonstrated by their admonitions about history being "under siege" or by their insistent counterpoising between their 'real' histories and the 'ideological' histories of their opponents, found, for example, in the dossiers about the disputes published in Journal of Social History and the Journal of American History, shortly after the events. Although these were valid concerns, especially given the authoritarian and indefensible Senate motions mentioned above, they still dealt with the discipline of history as being the only form, or the most legitimate, in which to discuss the past, and thus apparently did not perceive that it was only one of the many ways of representing the past in Western societies. While, on the one hand, historiography has great importance in the manner in which each society imagines its past, it is necessary to go beyond this and to consider history as a social practice involving the continual confrontation of pasts, some spurious, some not, it is in through this confrontation that there are born new, and perhaps more relevant, forms of imaging these same pasts. Therefore, for historians the recognition of this is fundamental for the discipline to acquire a new public importance, albeit at the cost of some of its oldest and dearest premises. For this reason, I agree with Antonis Liakos (2014, p. 4) when he states that the understanding of history as a social practice, expanded by the analyses of different history wars:

helps historians to understand better the complexity and the multiple dimensions of the environment in which we now work. History becomes an arena where social or ethnic groups demand their emancipation from the past stigmas and claim their participation to the shaping of the future. At the same ground, newly emerging elites establish their own hegemony undermining the authority of older ones. 
History wars thereby involve more than the conflict between different memories to the extent that they transcend problems involving, for example, the constitution of specific lieux de mémoires or the reliability of determined witnesses of victimization and/or subordination - although they also involved these questions. ${ }^{8}$ In that sense, history wars articulate certain specific demands about the role that historical knowledge and historiography should have in a given society; about the position of historians regarding themes of their present; and, finally, about the divergent meanings of conflicting historiographic productions, whether academic or not.

In summary, these wars can be won or lost; however, they will continue to happen the good (or bad...) intentions and humors of the discipline of history notwithstanding. Knowing how these conflicts occurred, and understanding the wider context which feeds them, is a fundamental step if we do not want to see our futures, if they still exist, consumed by pasts which we also do not desire - as the American history wars seem to demonstrate.

A preliminary version of this text was presented in the Opening Session of the III National Meeting of the History of the United States, held in November 2015 in Unirio (RJ). The author would like to thanks the organizers for the invitation and the productive comments on the paper.

${ }^{8}$ I would like to thank one of the peer reviewers for having raised the problem of memory and history wars. I intend to deal with this specific question at a later moment. 


\section{Bibliographic References}

140 CONG. REC. S - SENATE RESOLUTION 257. Relating to the Enola Gay exhibit, 19 set. 1994. Available at: <https://www.congress.gov/bill/103rd-congress/senate-resolution/257>. Accessed on: 24 Aug. 2015.

141 CONG. REC. S1282 - SENATE RESOLUTION 66. To prevent the adoption of certain national history standards, 20 Jan. 1995. Available at: <https://www.congress.gov/bill/104th-congress/ senate-resolution/66>. Accessed on: 24 ago. 2015.

AHR Forum: historiographic "turns" in critical perspective. The American Historical Review, v. 117, n. 3, pp. 698-812, jun. 2012.

BALDWIN, Peter. Hitler, the Holocaust and the historians dispute. Boston: Beacon Press, 1990. BARNES, Julian. The sense of an ending. London: Vintage Books, 2012.

BENDER, Thomas. Writing American history, 1789-1945. In: MACINTYRE, Stuart; MAIGUASCHA, Juan; PÓK, Attila (Org.). The Oxford history of historical writing: 1800-1945. Oxford: Oxford University Press, 2011. v. 4, pp. 369-389.

BERGER, Stefan. The power of national pasts: writing national history in nineteenth- and twentieth-century Europe. In: BERGER, Stefan (Org.). Writing the nation: a global perspective. London: Pallgrave-McMillan, 2007. pp. 30-62.

CHAKRABARTY, Dipesh. History and the politics of recognition. In: JENKINS, Keith; MORGAN, Sue; MUNSLOW, Alun (Org.). Manifestos for history. London: Routledge, 2007. p. 77-87.

CHENEY, Lynne. The end of history. The Wall Street Journal, New York: Dow Jones and Co., p. A26, 20 out. 1994.

CORRELL, John. The Smithsonian plan for the Enola Gay: a report on the revisions. Air Force Magazine, 1994a. Available at: <http://www.airforcemag.com/MagazineArchive/EnolaGayArchive/ Pages/default.aspx>. Accessed on: 20 Aug. 2015.

.War stories at Air and Space. Air Force Magazine, 1994b. Available at: <http://www.airforcemag.com/MagazineArchive/EnolaGayArchive/Pages/default.aspx>. Accessed on: 20 Aug. 2015. DE GROOT, Jerome. Consuming history: historians and heritage in contemporary culture. London: Routledge, 2009.

DIGGINS, John Patrick. Can the social historian get it right? Society, v. 34, n. 2, pp. 9-19, 1997. DUBIN, Steven C. Displays of power: controversy in the American museum from the Enola Gay to Sensation. New York: New York University Press, 1999.

ELEY, Geoff. The past under erasure? History, memory, and the contemporary. Journal of Contemporary History, v. 46, n. 3, pp. 555-573, 2011.

ENGELHARDT, Tom. The victors and the vanquished. In: ___ _ LINENTHAL, Edward (Org.). History wars: the Enola Gay and other battles for the American past. New York: Metropolitan Books, 1996. pp. 210-249.

EVANS, Richard. In defense of history. New York: W. W. Norton, 1999.

HARTMAN, Andrew. A war for the Soul of America: a history of the culture wars. Chicago: The University of Chicago Press, 2015.

HARTOG, François. Creer en la historia. Santiago de Chile: Universidad Finis Terrae, 2014.

HARWIT, Martin. An exhibit denied: lobbying the history of Enola Gay. New York: SpringerVerlag, 1996.

HISTORY after the Enola Gay controversy. The Journal of American History, v. 82, n. 3, pp. 10291135, Dec. 1995.

HUGGINS, Nathan. The deforming mirror of truth. Radical History Review, n. 49, pp. 25-48, inverno 1991.

HUNTER, James Davison. Culture wars: the struggle to define America. 2. ed. New York: Basic Books, 1992.

JAMESON, Fredric. Postmodernism or the cultural logic of late capitalism. New Left Review, n. 146, pp. 53-92, July/Aug. 1984.

KAMMEN, Michael. In the past lane: historical perspectives on American culture. Oxford: Oxford University Press, 1997.

LEO, John. History standards are bunk. U. S. News and World Report, Washington: U. S. News and World Report, v. 118, n. 5, p. 23, 6 Feb. 1995.

. The hijacking of American history. U. S. News and World Report, Washington: U. S. News and World Report, v. 117, n. 19, p. 36, 14 Nov. 1994. 
LIAKOS, Antonis. From the poetics of history to history as social practice, 2014. Available at: <https://www.academia.edu/4087481/History_as_Social_Practice>. Accessed on: 7 July. 2015. . History wars: notes from the field. Yearbook of the International Society for the Didactics of History. Augsburg: International Society for the Didactics of History, 2008-2009. pp. 57-74. LIMERICK, Patricia Nelson. Haunted America. In: Something in the soil: legacies and reckonings in the New West. 2. ed. New York: W. W. Norton, 2001. pp. 33-73.

LINENTHAL, Edward. Anatomy of a controversy. In:___ _ ENGELHARDT, Tom (Org.). History wars: the Enola Gay and other battles for the American past. New York: Metropolitan Books, 1996. pp. 9-62.

; ENGELHARDT, Tom (Org.). History wars: the Enola Gay and other battles for the American past. New York: Metropolitan Books, 1996.

LORENZ, Chris. Blurred lines: history, memory and the experience of time. International Journal for History, Culture and Modernity, v. 2, n. 1, pp. 43-62, 2014.

. Unstuck in time. Or: the sudden presence of the past. In: TILMANS, Karin; VREE, Frank van; WINTER, Jay (Org.). Performing the past: memory, history, and identity in modern Europe. 1. ed. Amsterdam: Amsterdam University Press, 2010. pp. 67-102.

MACINTYRE, Stuart; CLARK, Anna. The history wars. Melbourne: Melbourne University Publishing, 2003.

MCDOUGALL, Walter. What Johnny still won't know about history. Commentary Magazine, 1 July 1996. Available at: <https://www.commentarymagazine.com/articles/what-johnny-stillwont-know-about-history/>. Accessed on: 24 Aug. 2015.

. Whose history? Whose standards? Commentary Magazine, 1 May 1995. Available at: <https://www.commentarymagazine.com/articles/whose-history-whose-standards/>. Accessed on: 24 Aug. 2015.

NASH, Gary. The history standards controversy and social history. The Journal of Social History, v. 29, pp. 39-49, 1995.

1997.

et al. History on trial: culture wars and the teaching of the past. 2. ed. New York: Vintage,

NASH, Gerald. Creating the West: historical interpretations, 1890-1990. Albuquerque: University of New Mexico Press, 1993.

NEWMAN, Robert P. Enola Gay at Air and Space: anonymity, ignorance, hypocrisy. In: MADDOX. Robert (Org.). Hiroshima in history: the myths of revisionism. Columbia/London: University of Missouri Press, 2007. pp. 168-170.

NOVICK, Peter. That noble dream: the "objectivity question" and the American historical profession. Cambridge: Harvard University Press, 1988.

RODGERS, Daniel. The Age of Fracture. Princeton: Princeton University Press, 2011.

ROSENZWEIG, Roy. The best of times, the worst of times. The Journal of Social History, v. 29, pp. 99-107, 1995.

RUFER, Mario. La nación en enscenas: memorias publicas y usos del pasado en contextos poscoloniales. México: Colégio de Mexico, 2010.

STEARNS, Peter. Uncivil war: current American conservatives and social history. The Journal of Social History, v. 29, pp. 7-15, 1995.

SYMCOX, Linda. Whose history? The struggle for the National Standards in American classrooms. 1. ed. New York: Teachers College Press, 2002.

TYRRELL, Ian. Historians in the public: the practice of American history, 1890-1970. Chicago: The University of Chicago Press, 2005.

The absent Marx: class analysis and liberal history in $20^{\text {th }}$ century America. New York: Greenwood Press, 1986.

WHITE, Hayden. Politics, history and the practical past. Storia della Storiografia, v. 1, n. 61, pp. 127-134. 